\title{
POSSIBILITIES OF USE OF PRODUCTS FROM WASTE TYRE RECYCLING IN CONCRETE INDUSTRY
}

\author{
Dr Marijana Serdar* \\ Faculty of Civil Engineering, University of Zagreb , Zagreb, Croatia \\ Ana Baričević \\ Faculty of Civil Engineering, University of Zagreb , Zagreb, Croatia \\ Dr Dubravka Bjegović \\ Faculty of Civil Engineering, University of Zagreb , Zagreb, Croatia \\ Dr Stjepan Lakušić \\ Faculty of Civil Engineering, University of Zagreb , Zagreb, Croatia
}

Paper presents the effect of products obtained during recycling of waste tyres on properties of concrete. Only by taking into account specific properties of each product obtained by recycling, it is possible to apply them in concrete industry for preparation of concrete products with special properties. Products incorporating waste tyres can then be ecologically, technically and economically competitive alternative to products traditionally used in engineering practice.

Key words: Waste tyres, Recycled rubber, Recycled steel fibres, Recycled textile fibres

\section{INTRODUCTION}

Extensive use of tyres in car industry has resulted in accumulation of large quantities of used tyres that have to be disposed of at the end of their useful life. As many as 1.5 billon of tyres for the automobile industry are produced worldwide each year, and almost 3.5 million tons of waste tyres are generated in the EU countries alone [01]. According to the Directive 1999/31/EC [02], any form of disposal of used tyres in natural environment has been completely banned since 2006 and, following this decision, the quantity of available used tyres has grown considerably. Recent data show that the quantity of waste tyres disposed in an uncontrolled manner has reduced considerably in Europe over the past decade, and that it now amounts to no more than $4 \%$ of the total quantity of waste tyres. At the same time, it is estimated that $29 \%$ of waste tyres (about $450,000 \mathrm{t}$ or about 42.5 millions of tyres) are disposed of in an uncontrolled manner in new EU member countries. Tyre recycling belongs to the field of sustainable development as the recycling of used products results in valuable raw materials that can be used for manufacturing products with a new value. Three raw materials can be obtained by waste tyre recycling: a) rubber granules, b) steel fibres, and c) textile fibres (Figure 1).

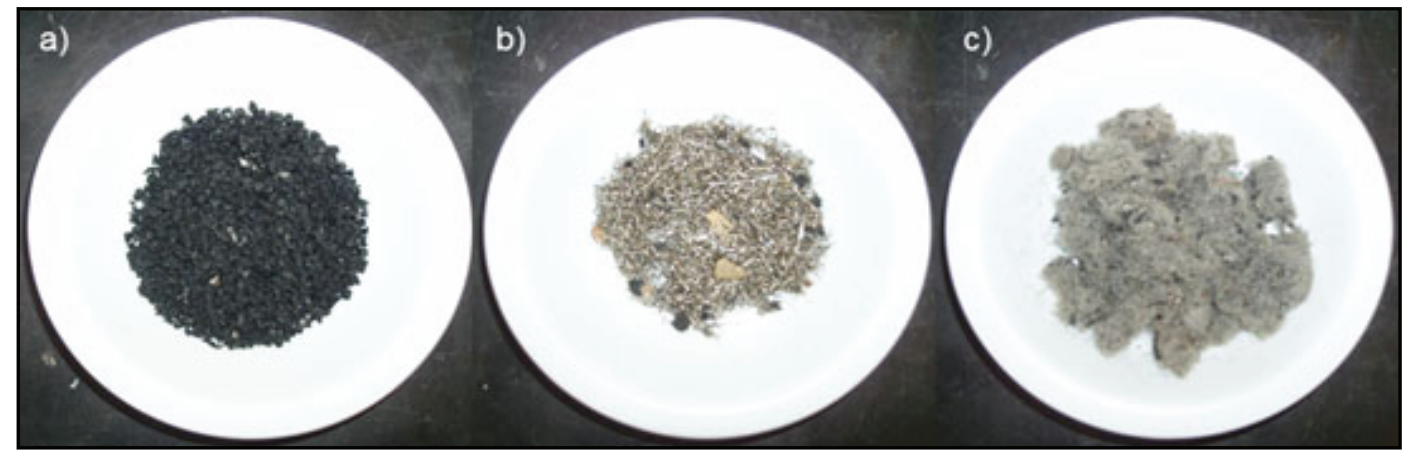

Figure 1: Products obtained by the automobile tyre recycling: a) rubber granules, b) steel fibres, and c) textile fibres [03]

* Faculty of Civil Engineering, University of Zagreb, Kačićeva 26, 10000 Zagreb, Croatia 
Only $5 \%$ of recycled waste tyres are currently used in construction industry, although the possibilities for such use are much greater in this field. In recent times, rubber has found its use in cement industry, in the production of surfaces for playfields and sports terrains, and as a component of various lining and covering products. In addition, one of new directions that has been studied over the past several years is the use of waste tyres and their components in the concrete manufacturing technology, since concrete technology is trying to reduce environmental impact of production, and at the same time contribute to the preservation of natural resources [04].

\section{USE OF RUBBER GRANULATES}

One of advantages of the use of rubber as a replacement for some of the aggregate is the reduction in the density of concrete mix. Furthermore, the nonpolarity of rubber, and roughness of its surface, result in introduction of an additional quantity of air $[03,05]$. The addition of rubber to the fresh concrete mixture also results in a reduced workability, especially when greater pro- portions are added ( $>30 \%$ of the total volume of aggregate) [05]. The replacement of aggregate with rubber reduces the compressive strength and stiffness in the composite, which could have been expected considering the physical and mechanical properties of rubber compared to stone aggregate. The capability of rubber to reject water, due to hydrophobicity of its surface, and consequent introduction of an additional quantity of air into the mixture, ensures a greater quantity of closed pores in the composite structure that are not available to water [06]. This is why these composites have a lower capability to absorb water by capillary absorption. Despite a lower capillary absorption, the presence of rubber particles causes higher penetration of water under pressure, due to the poor quality of the rubber to cement matrix interface, but also to physical properties of rubber which "shrinks" when subjected to high water pressure [07]. Furthermore, physical properties of rubber enable this material to behave as an absorber of internal stress due to hydrostatic pressure of water during the freezing and thawing cycle $[05,08]$.

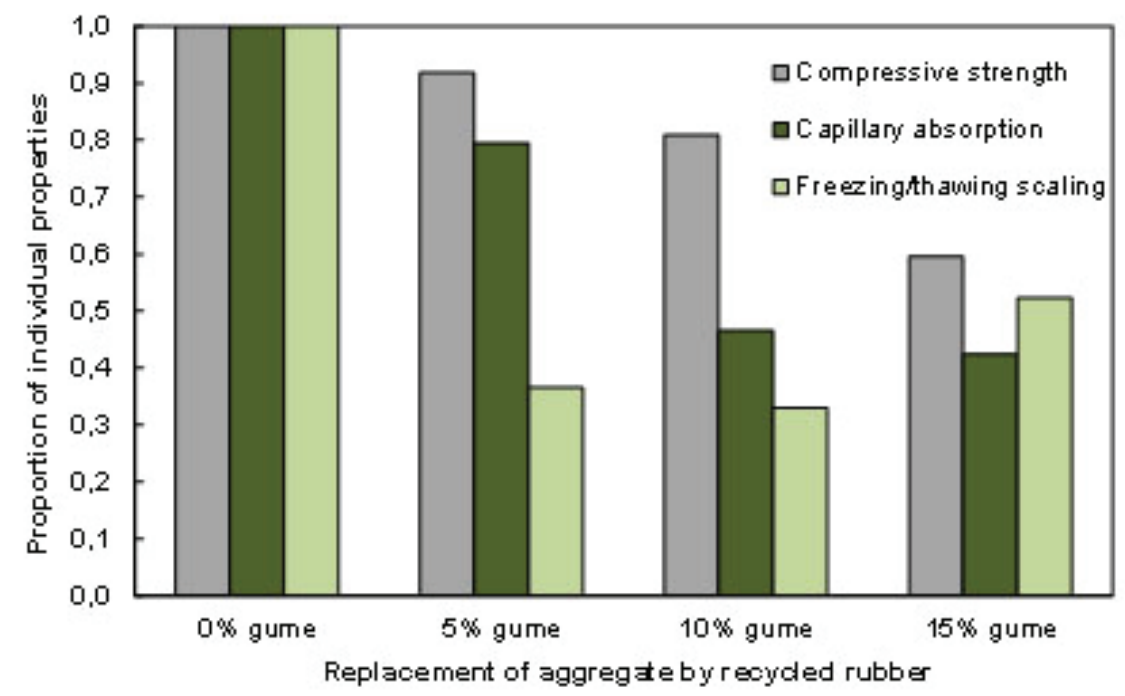

Figure 3: Influence of aggregate replacement with recycled rubber on hardened concrete

a)
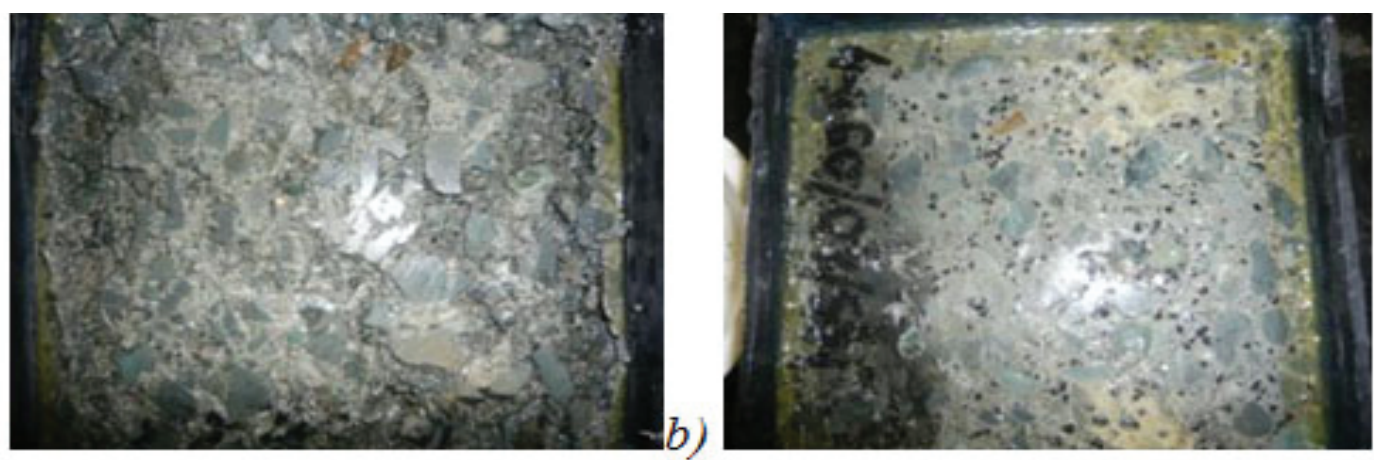

Figure 4: Structure of concrete without rubber (a) and $10 \%$ of rubber (b) after exposure to freezing and thawing cycles with deicing salt 
Presented main influences of incorporating rubber in concrete mixture make the recycled tyre attractive for use in construction industry, where compressive strength is not prevailing factor, but durability in aggressive environments. It is precisely because of these properties that new trends in the use of rubber in concrete are oriented toward development of products in which good use can be made of its insulating and absorbing properties $[03,09]$, its capacity to absorb energy in high-strength concrete [10], and as a replacement for chemical admixtures that are used for increasing resistance to freezing and thawing [05].

\section{USE OF RECYCLED STEEL FIBRES}

Studies conducted so far to define possibilities for the use of steel fibres from waste tyres have revealed several positive features of this material $[03,10,11]$. In fact, recycled fibres are an economically and environmentally justified alternative to industrial fibres, especially when used in greater proportions and if mixed with industrial fibres [12]. They limit propagation of cracks and increase toughness of the composite compared to ordinary concrete, even in case of separation and pulling out of the composite [13]. A comparison of fibre reinforced concrete containing industrial fibres, with fibre reinforced concrete containing the same and higher quantity of recycled fibres obtained by automobile tyre recycling, is presented in form of diagram in Figure 5. This diagram shows that the design of mixes with recycled fibres results in properties that are similar to those of mixes prepared with industrial fibres.

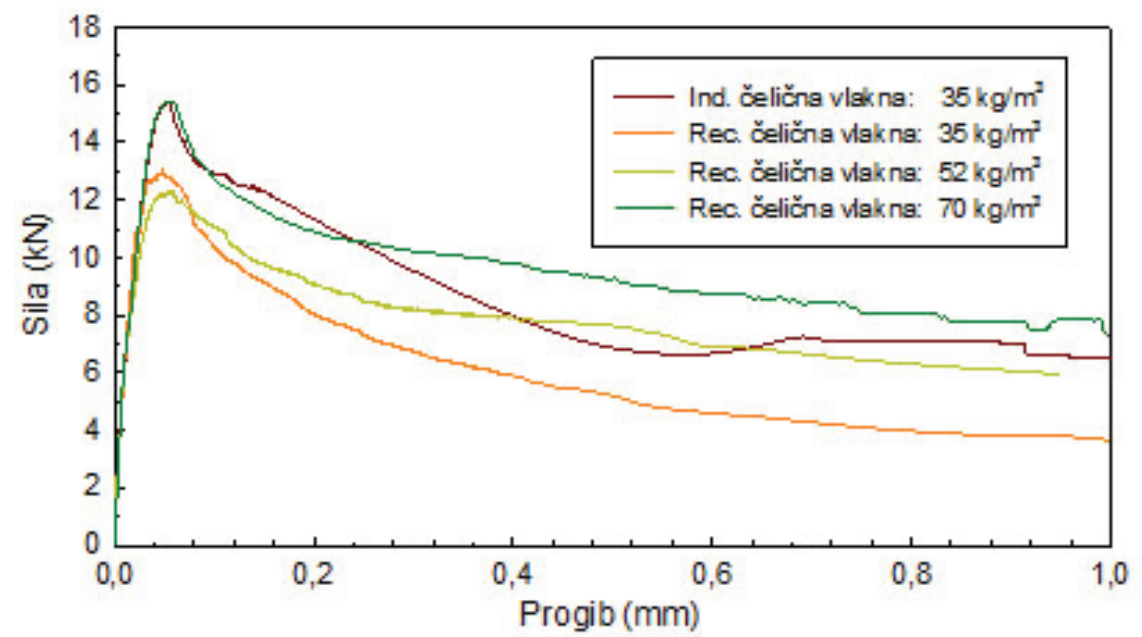

Figure 5: Working diagram of fibre reinforced concretes containing different types and quantities of steel fibres during ductility testing

In addition to its influence on ductility, the introduction of steel fibres in fibre reinforced concrete can result in some other benefits. Preliminary research has revealed that fibre reinforced concrete mixes prepared with cleaned recycled steel fibres are characterized by lower incidence of scaling when subjected to freezing and thawing cycles [14]. In addition, it was established that such fibre reinforced concrete is less susceptible to wearing and corrosion when exposed to aggressive marine environment $[15,16]$. Therefore, recycled steel fibre reinforced concrete can be used for preparation of prefabricated elements in cases where a considerable resistance to bending, and also to dynamic and impact load, is required, such as prefabricated railway tracks on concrete bedding [17].

\section{USE OF RECYCLED TEXTILE FIBRES}

The last product of waste tyre recycling is textile fibres. These fibres have not so far found their use in construction industry. Preliminary research has shown that the influence of recycled textile fibres on the reduction of shrinkage due to drying is similar to that of industrial polypropylene fibres (Figure 6) [18]. If an increase in deformation due to concrete drying is compared with values for the same concrete without fibres, calculated according to Eurocode 2, it can be seen that the reduced shrinkage can be observed in the first days of the concrete matrix hardening process. When such recycled fibres are used, the concrete shrinkage is visibly reduced, and hence the risk of cracking due to improper or insufficient curing is also lowered. 


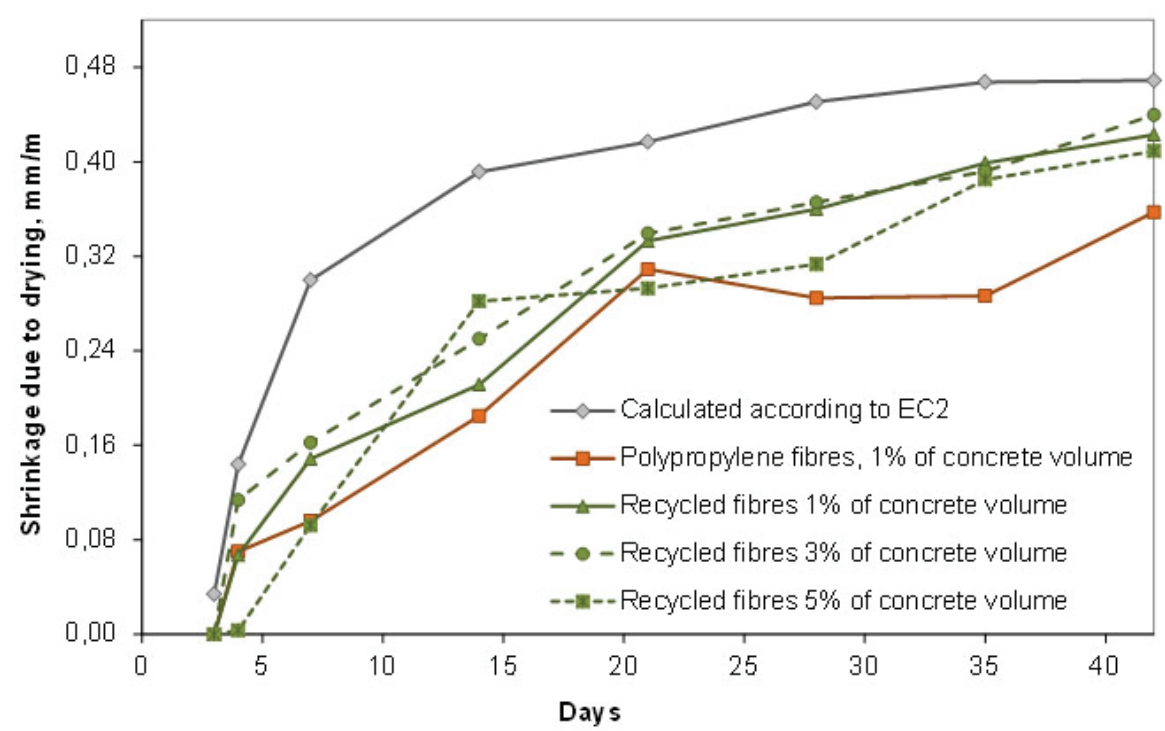

Figure 6: hrinkage due to drying calculated according to EC2 for ordinary concrete, and measured for textile fibre reinforced concrete

In addition to reduced shrinkage due to drying, the recycled textile fibres have also some other positive influences on concrete durability, such as a higher resistance to penetration of chlorides and a reduced penetration of water. These results show that the potential application of textiles is in repair mortars, where it is extremely important to prevent occurrence of micro-cracks and penetration of aggressive substances.

\section{CONCLUSION}

Three types of materials are obtained in the waste tyre recycling process: rubber granulates, steel fibres, and polymer fibres. The way in which concrete properties are influenced by each of these materials, when used as secondary raw materials, is explained in the paper. Rubber granules reduce compressive strength of concrete but, at the same time, they increase resistance to freezing and thawing, and the sound absorption capability. The addition of recycled steel fibres increases ductility of concrete, and prevents propagation of cracks. The addition of textile fibres reduces deformations due to shrinkage, and positively influences durability properties of concrete. Taking into account their influences on concrete, each of these materials can be used to prepare ecologically, technically and economically competitive alternative to products that are nowadays dominantly used in the engineering practice.

\section{ACKNOWLEDGEMENT}

The research presented in this paperwas conducted in the scope of project "Rubberized Concrete
Noise Barriers", RUCONBAR ECO/10/277317, financed by the European Commission Eco-innovation initiative, European Agency for Competitiveness and Innovation (EACl), and project ECOTRACK, financed by the BICRO agency in the scope of the Proof of Innovative Concept initiative. Special thanks are extended to the companies that have continuously supported research undertaken in this area: Viadukt d.d (TBP Pojatno), Gumiimpex - GRP d.o.o., Beton Lučko d.o.o. and Holcim Croatia.

\section{REFERENCES}

1) Bjegović, D., Baričević, A., Lakušić, S., Damjanović, D., Duvnjak, I.: Positive interaction of industrial and recycled steel fibres in fibre reinforced concrete. Journal of Civil Engineering and Management (2012). (prihvaćen za objavljivanje).

2) Bjegovic, D., Baricevic, A., Lakusic, S.: Rubberized hybrid fibre reinforced concrete, International Conference Microstructural - related Durability of Cementitious Composites, RILEM Proceedings PRO 83. Amsterdam: Rilem Publications s.a.r.I., 2012.

3) Bjegović, D., Baričević, A., Serdar, M.: Durability properties of concrete with recycled waste tyres // 12th International Conference on Durability of Building Materials and Components Porto, Faculdade de Engenharia Universidade do Porto, 2011. pp. 1659-1667

4) Bjegović, D., Serdar, M., Jelčić Rukavina, M., Baričević, A.: Istraživanja kriterija održivosti armiranog betona. GRAĐEVINAR (2010.) 62, 10; pp. 931-940

Journal of Applied Engineering Science 12(2014)1, 281 
5) Council of the European Union, "Council Directive 1999/31/EC of 26 April 1999 on the land fill of waste," 1999.

6) Čović, M. Optimalizacija svojstava morta $s$ različitim udjelima reciklirane gume, završni rad - preddiplomski studij. Zagreb : Građevinski fakultet, 11.09. 2012, 61 str. voditelj: Bjegović, D., neporedni voditelj: Baričević, A.

7) ETRMA - European tyre and rubber manufacturers association, "End of life tyres - A valuable resource with growing potential," 2010.

8) EU Projekt "Rubberized Concrete Noise Barriers", RUCONBAR ECO/10/277317 www. ruconbar.com

9) Ganjian, E., Khorami, M., Maghsoudi, A.A.: Scrap-tyre-rubber replacement for aggregate and filler in concrete. Construction and Building Materials (2009), 23(5), pp. 1828-1836.

10) Kovačević, J.: Promjena svojstava recikliranog hibridnog mikroarmiranog betona uslijed izloženosti agresivnom okolišu / završni rad - diplomski/integralni studij. Zagreb, Građevinski fakultet, 14.02. 2013, 68 str. voditelj: Bjegović, D., neposredni voditelj: Baričević, A.

11) Lakušić, S., Baričević, A., Damjanović, D., Duvnjak, I., Haladin, I.: Kolosijek na betonskoj podlozi - ECOTRACK, Građenje prometne infrastrukture. Zagreb: Građevinski fakultet Sveučilišta u Zagrebu, Zavod za prometnice, 2012, pp. 7-49.

12) Marasović, I.: Utjecaj mikroarmiranja recikliranim vlaknima na svojstva betona / diplomski rad. Zagreb : Građevinski fakultet, 03.12. 2009, 120 str. voditelj: Bjegović, D., neposredni voditelj: Serdar, M.
13) Mokos, I.: Procjena trajnosti mikroarmiranih betona u morskom okolišu primjenom potenciostatske anodne polarizacije / završni rad - diplomski/integralni studij. Zagreb : Građevinski fakultet, 14.02. 2013, 87 str. voditelj: Bjegović, D., neposredni voditelj: Baričević, A.

14) Neocleous, K., Angelakopoulos, H., Pilakoutas, K., Guadagnini, M.: Fibre - reinforced roller-compacted concrete transport pavements. Proceeding of the ICE - Transport (2011), 164(2), 97-109.

15) Petti, K., Marinac, L.: Betoni s otpadnim tekstilnim vlaknima, Dekanova nagrada, Zagreb, Građevinski fakultet, 2010., voditelj: Bjegović, D., neposredni vodit

16) Serdar, M.; Baričević, A.; Lakušić, S.; Bjegović, D. Betonski proizvodi specijalne namjene od reciklata otpadnih guma. // Građevinar : časopis Hrvatskog saveza građevinskih inženjera. 65 (2013) , 9; 793801

17) Skripkiūnas, G., Grinys, A., Janavičius, E.: (2010). Porosity and Durability of Rubberized Concrete. http://www.claisse.info/ 2010\%20papers/m55.pdf

18) Tlemat, H., Pilakoutas, K., \& Neocleous, K. Stress-strain characteristic of SFRC using recycled fibres. Materials andStructures (2006), 39, 365-377.

Paper sent to revison: 07.02.2014.

Paper ready for publication: 15.03.2014. 